\title{
Associations between insulin resistance and TNF- $\alpha$ in plasma, skeletal muscle and adipose tissue in humans with and without type 2 diabetes
}

\author{
P. Plomgaard • A. R. Nielsen • C. P. Fischer • \\ O. H. Mortensen • C. Broholm • M. Penkowa • \\ R. Krogh-Madsen • C. Erikstrup • B. Lindegaard • \\ A. M. W. Petersen - S. Taudorf • B. K. Pedersen
}

Received: 1 July 2007 / Accepted: 15 August 2007 / Published online: 10 October 2007

(C) Springer-Verlag 2007

\begin{abstract}
Aims/hypothesis Clear evidence exists that TNF- $\alpha$ inhibits insulin signalling and thereby glucose uptake in myocytes and adipocytes. However, conflicting results exist with regard to the role of TNF- $\alpha$ in type 2 diabetes.

Methods We obtained blood and biopsy samples from skeletal muscle and subcutaneous adipose tissue in patients with type 2 diabetes $(n=96)$ and healthy controls matched for age, sex and BMI $(n=103)$.

Results Patients with type 2 diabetes had higher plasma levels of fasting insulin $(p<0.0001)$ and glucose $(p<0.0001)$ compared with controls, but there was no difference

P. Plomgaard • A. R. Nielsen • C. P. Fischer - O. H. Mortensen •

C. Broholm · R. Krogh-Madsen · C. Erikstrup • B. Lindegaard •

A. M. W. Petersen $\cdot$ S. Taudorf $\cdot$ B. K. Pedersen

Centre of Inflammation and Metabolism, Department of Infectious

Diseases, Rigshospitalet, Faculty of Health Sciences,

University of Copenhagen,

Copenhagen, Denmark

P. Plomgaard - A. R. Nielsen • C. P. Fischer - O. H. Mortensen •

C. Broholm • R. Krogh-Madsen • C. Erikstrup • B. Lindegaard •

A. M. W. Petersen $\cdot$ S. Taudorf $\cdot$ B. K. Pedersen

Copenhagen Muscle Research Centre,

Copenhagen, Denmark

M. Penkowa

Centre of Inflammation and Metabolism, Section of

Neuroprotection, Panum Institute, Faculty of Health Sciences,

University of Copenhagen,

Copenhagen, Denmark

\section{P. Plomgaard $(\triangle)$}

Centre of Inflammation and Metabolism, Rigshospitalet,

Section 7641, Blegdamsvej 9,

DK-2100 Copenhagen, Denmark

e-mail: plomgaard@dadlnet.dk
\end{abstract}

between groups with regard to fat mass. Plasma levels of TNF- $\alpha(p=0.0009)$ and soluble TNF receptor 2 (sTNFR2; $p=0.002$ ) were elevated in diabetic patients. Insulin sensitivity was correlated with quartiles of plasma TNF- $\alpha$ after adjustment for age, sex, obesity, WHR, neutrophils, IL-6 and maximum $\mathrm{O}_{2}$ uptake $\left(\dot{V} \mathrm{O}_{2} / \mathrm{kg}\right)$ in the diabetes group $(p<0.05)$. The TNF mRNA content of adipose or muscle tissue did not differ between the groups, whereas muscle TNF- $\alpha$ protein content, evaluated by western blotting, was higher in type 2 diabetic patients. Immunohistochemistry revealed more TNF- $\alpha$ protein in type 2 than in type 1 muscle fibres.

Conclusions/interpretation After adjustment for multiple confounders, plasma TNF- $\alpha$ is associated with insulin resistance. This supports the idea that TNF- $\alpha$ plays a significant role in the pathogenesis of chronic insulin resistance in humans. However, findings on the TNF- $\alpha$ protein levels in plasma and skeletal muscle indicate that measurement of TNF mRNA content in adipose or muscle tissue provides no information with regard to the degree of insulin resistance.

Keywords Cytokines · Insulin resistance · Insulin sensitivity · Low-grade inflammation · Metabolic syndrome

$\begin{array}{ll}\text { Abbreviations } \\ \text { CRP } & \text { C-reactive protein } \\ \text { HOMA2-IR } & \begin{array}{l}\text { Homeostasis model assessment of insulin } \\ \text { resistance, version } 2\end{array} \\ \text { proTNF- } \alpha & \text { membrane-bound form of TNF- } \alpha \\ \text { sTNFR2 } & \text { Soluble TNF receptor } 2 \\ \dot{V} \mathrm{O}_{2} & \text { maximum } \mathrm{O}_{2} \text { uptake }\end{array}$




\section{Introduction}

Low-grade inflammation is associated with the metabolic syndrome and type 2 diabetes $[1,2]$. Several studies have demonstrated association between circulating TNF- $\alpha$, obesity and type 2 diabetes [3-5], whereas other studies have failed to do so $[6,7]$. A direct effect of TNF- $\alpha$ on insulin sensitivity in skeletal muscle has been demonstrated in vitro [8], in vivo in animals [9] and in vivo in humans [10]. TNF- $\alpha$ inhibits the insulin signalling cascade at several pivotal regulatory proteins, such as the insulin receptor substrate (IRS) and Akt substrate 160 in human skeletal muscle in vitro [11] and in vivo [10]. These two studies indicate that elevated TNF- $\alpha$ is not secondary to the pathological conditions associated with insulin resistance, but that TNF- $\alpha$ plays a direct pathogenic role in glucose metabolism.

Impaired insulin sensitivity in skeletal muscle is a major feature of type 2 diabetes [12]. An increased amount of TNF- $\alpha$ protein in skeletal muscle has been found in patients with insulin resistance [13] and chronic obstructive pulmonary disease [14]. Regular exercise improves insulin sensitivity [15] and the amount of TNF- $\alpha$ protein is reduced by resistance exercise in frail elderly patients [16].

Obesity is strongly associated with reduced insulin sensitivity [17], and increased expression of TNF mRNA in human adipose tissue from obese patients has been demonstrated [18]; however, this is not a consistent finding [19]. Furthermore, it has been suggested that obese patients have a higher level of membrane-bound TNF- $\alpha$ than lean subjects [20], whereas release of TNF- $\alpha$ from human adipose tissue into the circulation has yet to be demonstrated in vivo [21]. Interestingly, it may not be the adipocytes per se, but the surrounding stromal cellsincluding macrophages - that produce most of the TNF- $\alpha$ in the adipose tissue [22].

Shedding of TNF receptor 2 (TNFR2) from plasma membranes seems changed in type 2 diabetes [23] and soluble TNFR2 (sTNFR2) has been demonstrated to correlate negatively with insulin sensitivity [23]. Furthermore, upon activation of TNFR2 the receptor is cleaved and shed into the circulation, where it can be measured as sTNFR2 [24]. The amount of sTNFR2 in the circulation could therefore be interpreted as the degree of activation of TNF- $\alpha$ signalling in the tissues, making sTNFR2 an interesting parameter for TNF- $\alpha$ activation in the tissues.

The aim of the present study was to test the hypothesis that elevated levels of TNF- $\alpha$ in plasma, muscle and adipose tissue and plasma levels of sTNFR2 are associated with insulin resistance independently of obesity. Given that type 2 diabetes and obesity often coexist and that several other factors might influence the levels of TNF- $\alpha$, we studied the levels of TNF- $\alpha$ using a cross-sectional case- control design in which patients with type 2 diabetes and healthy controls were closely matched, not only according to age and sex but also according to BMI.

\section{Methods}

Study design A cross-sectional case-control design was employed. Participants $(n=199)$ were recruited by advertising in a local newspaper and information on the diagnosis of type 2 diabetes was based on oral information from each subject. Participants received oral and written information about the experimental procedures before giving their written informed consent. The study was approved by the Ethics Committee of the Copenhagen and Frederiksberg Communities (KF 01-141/04). To verify the diagnosis, the WHO diagnostic criteria for type 2 diabetes were used, and the participants were thus divided into 103 healthy controls and 96 patients with type 2 diabetes. Participants were screened to isolate metabolic conditions other than type 2 diabetes that are known to influence body composition and the immune system. Exclusion criteria were treatment with insulin, recent or ongoing infection, a history of malignant disease, and known dementia. Participants reported to the laboratory between 08:00 and 10:00 hours after an overnight fast. They did not take any medication in the $24 \mathrm{~h}$ preceding the examination, and those with type 2 diabetes did not take their oral glucose-lowering medication for 1 week preceding the examination. A general health examination was performed. Sphygmomanometric measurement of brachial blood pressure was performed while the participants were resting in the supine position. Blood samples were drawn from an antecubital vein. An OGTT was performed on the same day.

OGTT Blood samples were drawn before and 1 and $2 \mathrm{~h}$ after the participant drank $500 \mathrm{ml}$ of water containing $75 \mathrm{~g}$ of dissolved glucose. The WHO diagnostic criteria were applied. Participants found to have IGT were excluded from the study.

Plasma samples Blood samples were drawn into glass tubes containing EDTA, which were immediately spun at $3,500 \times \mathrm{g}$ for $15 \mathrm{~min}$ at $4^{\circ} \mathrm{C}$. Plasma was isolated and stored at $-20^{\circ} \mathrm{C}$ until analysed. Plasma concentrations of TNF- $\alpha$, sTNFR2 and IL-6 were measured by ELISA (R\&D Systems, Minneapolis, MN, USA). Samples were analysed in duplicate and mean concentrations were calculated. In plasma, levels of cholesterol (HDL and LDL), triacylglycerol, C-reactive protein (CRP), glucose and insulin were measured using routine laboratory methods. Based on the fasting plasma concentrations of glucose and insulin, the level of insulin resistance was calculated using the homeo- 
stasis model assessment of insulin resistance, version 2 (HOMA2-IR) (software available at http://www.dtu.ox.ac. uk/, last accessed in August 2007) [25].

Tissue samples Biopsies were obtained from skeletal muscle and adipose tissue using a Bergström biopsy needle [26]. The biopsies were immediately frozen in liquid nitrogen and stored at $-80^{\circ} \mathrm{C}$ until analysed. From the muscle biopsies, mRNA was obtained from 94 controls and 83 diabetic patients and from the adipose tissue biopsies mRNA was obtained from 84 controls and 83 diabetic patients.

$R N A$ isolation, reverse transcription and real-time PCR Total RNA was extracted from $\sim 40 \mathrm{mg}$ muscle or adipose tissue using Trizol Reagent (Invitrogen, Carlsbad, CA, USA) following the manufacturer's instructions. In summary, muscle tissue was homogenised in $1 \mathrm{ml}$ Trizol Reagent for $15 \mathrm{~s}$ using a Qiagen Tissuelyser (Qiagen Nordic, Copenhagen, Denmark). Chloroform was added and the phases were separated by centrifugation. The aqueous phase with the RNA was transferred to a fresh tube and the RNA precipitated by adding isopropanol and left at $-20^{\circ} \mathrm{C}$ for $1 \mathrm{~h}$. After another centrifugation, the RNA pellet was washed in $75 \%$ ethanol and finally dissolved in $50 \mu 1$ diethylpyrocarbonate-treated water.

The RNA concentration was determined spectrophotometrically and $2 \mu \mathrm{g}$ total RNA was reversed-transcribed in a total volume of $100 \mu \mathrm{l}$ using the Taqman Reverse Transcription Kit (Applied Biosystems, Branchburg, NJ, USA) and random hexamers as primers.

Real-time PCR was performed using an ABI 7900 Sequence Detection System (Applied Biosystems). The mRNAs for $T N F$ and the endogenous control, $\beta$-actin, were amplified using predeveloped assays (Applied Biosystems). The PCR conditions followed the procedure recommended by the manufacturer, with $10 \mu \mathrm{l}$ reaction volume and each sample run in triplicate for 50 cycles. The mRNA content of both the target and the endogenous control gene was calculated from the cycle threshold values by using a standard curve constructed from a serial dilution of aliquots of cDNA pooled from all the samples.

Muscle TNF- $\alpha$ protein quantification Muscle TNF- $\alpha$ protein was measured in a subpopulation consisting of 16 controls (eight of normal weight and eight obese) and 16 diabetic patients (eight of normal weight and eight obese). They were matched according to age and sex.

Muscle lysate Muscle tissue was freeze-dried and dissected free of visual blood, fat and connective tissues. Muscle lysate was then prepared by mixing the muscle tissue with a modified RIPA cell lysis buffer $(50 \mathrm{mmol} / \mathrm{l}$ Tris-HCl, $\mathrm{pH} 7,4$, $150 \mathrm{mmol} / 1 \mathrm{NaCl}, 1 \mathrm{mmol} / 1 \mathrm{EGTA}, 1 \mathrm{mmol} / \mathrm{l}$ EDTA, $0.25 \%$ sodium deoxycholate, $1 \%$ Triton X) containing $1 \mu \mathrm{g} / \mathrm{ml}$ pepstatin A, $1 \mathrm{mmol} / 1$ sodium orthovanadate, $1 \mathrm{mmol} /$ 1 sodium fluoride, and a complete protease inhibitor cocktail (Roche, Basel, Switzerland) followed by homogenisation in precooled racks using a Tissuelyser (Qiagen, Valencia, CA, USA) for $1 \mathrm{~min}$ at $30 \mathrm{~Hz}$ followed by 15 min incubation on ice. Homogenisation and incubation on ice were repeated two or three times to obtain the required degree of homogenisation. Homogenates were then rotated end over end for $1 \mathrm{~h}$ at $4^{\circ} \mathrm{C}$ and centrifuged at $16,000 \times g$ at $4^{\circ} \mathrm{C}$ for $1 \mathrm{~h}$. The supernatant protein concentrations were determined using the Bio-Rad DC kit (Bio-Rad, Hercules, CA, USA) using BSA as standard. All determinations were done in triplicate.

Western blotting Twenty-five micrograms of muscle protein lysate per lane was boiled in Laemmli buffer and separated on $12 \%$ Bis-Tris gels (Invitrogen, Taastrup, Denmark) and transferred to PVDF (polyvinylidene difluoride) membranes (Hybond-P; GE Healthcare, Little Chalfont, UK). Membranes were then blocked for $1 \mathrm{~h}$ at room temperature in blocking buffer [Tris-buffered saline with $0.1 \%$ Tween 20 and 5\% Top-Block (Sigma-Aldrich, St Louis, MO, USA)]. The membranes were then incubated overnight at $4^{\circ} \mathrm{C}$ in a blocking buffer containing a primary antibody against human TNF- $\alpha$ (catalogue no. 3707; Cell Signaling Technology, Danvers, MA, USA) at 1:1,000 dilution. The membranes were then washed three times for $5 \mathrm{~min}$ in a wash buffer (Tris-buffered saline with $0.1 \%$ Tween 20 ) and incubated for $1 \mathrm{~h}$ at room temperature with secondary antibody (goat anti-rabbit horseradish peroxidase, P0448; Dako, Glostrup, Denmark) at 1:15,000 dilution in blocking buffer, followed by three 5-min washes in wash buffer. The protein bands were detected using Supersignal West Femto (Pierce, Rockford, IL, USA) and quantified using a CCD image sensor (ChemiDoc XRS; Bio-Rad) and software (Quantity One; Bio-Rad). Following detection, the membranes were stripped in strip buffer (25 mmol/l glycine, 1\% SDS, $\mathrm{pH} 2$ ) for $1-2 \mathrm{~h}$ and then blocked in blocking buffer for $1 \mathrm{~h}$ at room temperature. In order to normalise for equal protein, the membranes were reprobed overnight at $4^{\circ} \mathrm{C}$ with anti- $\beta$-actin (A3853; Sigma) at 1:5,000 dilution in blocking buffer, followed by washing and incubation for $1 \mathrm{~h}$ with secondary antibody (anti-mouse horseradish peroxidase, P0260; Dako) at 1:2,000 dilution in blocking buffer, followed by three 5 -min washes in a wash buffer. The protein bands were detected using enhanced chemiluminescence (ECL; Amersham Biosciences, Little Chalfont, Bucks, UK) and quantified using a CCD image sensor (ChemiDoc XRS) and software (Quantity One). The content of TNF- $\alpha$ protein (cleaved form or membrane-bound) was expressed as arbitrary units relative to $\beta$-actin protein content. 
Muscle TNF- $\alpha$ histology Muscle samples from eight healthy controls and eight diabetic patients were evaluated for TNF- $\alpha$ by immunohistochemistry. The subjects were matched according to sex, age and obesity. For identification of muscle fibres, frozen biopsies of the vastus muscles were cut on a cryostat at $-20^{\circ} \mathrm{C}$ in $6 \mu \mathrm{m}$ consecutive transverse sections. All sections were immediately collected on glass slides.

Histology We used rouine ATPase histochemistry performed after preincubation at $\mathrm{pH} 4.57$ and $\mathrm{pH} 10.30$.

Immunohistochemistry For the immunostaining procedure, we applied enzymatic epitope retrieval, for which the sections were preincubated overnight in a Tris-EGTA buffer $(1.211 \mathrm{~g}$ Tris, $0.95 \mathrm{~g}$ EGTA, 11 distilled water) at $60^{\circ} \mathrm{C}$ and afterwards in $1.5 \% \mathrm{H}_{2} \mathrm{O}_{2}$ in Tris-buffered saline (TBS)/Nonidet (TBS $0.05 \mathrm{~mol} / 1 \mathrm{Tris}, \mathrm{pH} 7.4,0.15 \mathrm{~mol} / \mathrm{l} \mathrm{NaCl}$; with $0.01 \%$ Nonidet P-40) (code N-6507; Sigma-Aldrich) for $15 \mathrm{~min}$ at room temperature $\left(20^{\circ} \mathrm{C}\right)$ to quench endogenous peroxidase. Subsequently, sections were incubated in $10 \%$ goat serum (code 04009-1B; In Vitro, Fredensborg, Denmark) for $30 \mathrm{~min}$ at room temperature in order to block potential, non-specific binding of the primary and secondary antibodies. Afterwards, sections were incubated overnight at $4^{\circ} \mathrm{C}$ with polyclonal rabbit anti-TNF- $\alpha$ diluted $1: 100$ (catalogue no. AMC3012; Biosource, Solingen, Germany).

Primary antibodies were detected using biotinylated antirabbit immunoglobulin $G$ diluted 1:400 (catalogue no. B3275; Sigma-Aldrich) followed by streptavidin-biotinperoxidase complex (StreptABComplex/horseradish peroxidase; DakoCytomation, Glostrup, Denmark) for $30 \mathrm{~min}$ at room temperature. Afterwards, staining was enhanced using biotinylated tyramide and streptavidin-peroxidase complex (catalogue no. NEL700A; NEN Life Science Products, Boston, MA, USA) prepared according to the manufacturer's recommendations. The immunoreaction was visualized using $0.015 \% \mathrm{H}_{2} \mathrm{O}_{2}$ in 3,3-diaminobenzidine tetrahydrochloride/ TBS for $10 \mathrm{~min}$ at room temperature. Sections were always processed and stained simultaneously and under the same laboratory conditions.

Negative control sections were incubated without the primary or secondary antibody or in the blocking serum. Results were considered only if these controls were negative.

To determine the degree of false-positive staining due to endogenous biotin, we pretreated sections sequentially with Cruz Block Avidin/Biotin blocking kit (catalogue no. sc24967; Santa Cruz Biotechnology, Santa Cruz, CA, USA) before immunohistochemistry was performed. This approach revealed that muscular endogenous biotin is unlikely to induce a false-positive signal by binding to the streptavidin included in the immunohistochemistry process. In order to assess the specificity of the primary antibodies, we preabsorbed these with their corresponding human antigen for 2 at $20^{\circ} \mathrm{C}$. We used human TNF- $\alpha$ (catalogue no. sc-1350P; Santa Cruz Biotechnology). Results were considered only when this preabsorbtion resulted in negative immunostaining. For the simultaneous examination and recording of staining we used a Zeiss Axio Imager D1 microscope with an AxioCam MRc5 camera.

Statistics Data are generally presented as mean \pm SEM. If the data were not normally distributed, logarithmic transformation was applied and the data are presented as geometric mean and geometric SEM. For comparisons between groups (controls and diabetic patients) the Student's $t$ test was used for continuous variables and the $\chi^{2}$ test for categorical variables. Levels of TNF- $\alpha$, sTNFR2 in plasma and TNF mRNA in muscle and adipose tissue were correlated with various clinical and paraclinical parameters based on the Spearman correlation and were divided into quartiles. Multiple regression analysis was done using a general linear model. For evaluation of the protein content in muscle, twoway ANOVA was performed and the Student's $t$ test with Bonferroni correction was used as a post hoc test. The residuals obtained from the regression and ANOVA models were further evaluated and the model was only accepted if the residuals were normally distributed. All analyses were performed using SAS software version 9.1 (SAS Institute, Cary, NC, USA). Significance was accepted at $p<0.05$.

\section{Results}

Clinical and laboratory variables The cohort consisted of 96 patients with type 2 diabetes and 103 healthy controls. Patient characteristics appear in Table 1 . There were no differences with regard to sex and obesity, but the control group had a slightly lower mean age than the diabetes group $(p<0.05)$. Fasting glucose and insulin, $\mathrm{HbA}_{1 \mathrm{c}}$ and HOMA2-IR were elevated in the diabetic group. The total percentage fat mass, determined by dual-energy X-ray absorptiometry scanning, did not differ between groups, but WHR and triacylglycerol were higher in the diabetes group compared with the controls. HDL-cholesterol was lower in the group of diabetic patients; however, LDLcholesterol was also lower in the diabetic group when compared with the controls. Markers of increased inflammation (neutrophil number, CRP, TNF- $\alpha$, sTNFR2 and IL-6) were elevated in the diabetes group. However, no difference was observed for orosomucoid.

Surprisingly, there were no significant differences between the two groups with regard to $T N F-\alpha$ mRNA content in muscle or adipose tissue (Table 1). 
Table 1 Clinical and laboratory variables in healthy controls and patients with type 2 diabetes

\begin{tabular}{|c|c|c|c|c|c|}
\hline & \multicolumn{2}{|c|}{ Healthy controls } & \multicolumn{3}{|c|}{ Type 2 diabetes $(n=96)$} \\
\hline & Mean & $95 \% \mathrm{CI}$ & Mean & $95 \% \mathrm{CI}$ & $p$ value \\
\hline \multicolumn{6}{|l|}{ Clinical } \\
\hline Age (years) & 52.9 & $50.5-55.3$ & 58.2 & $56.1-60.4$ & 0.0014 \\
\hline Sex (female/male) & $33 / 70$ & - & $24 / 72$ & - & $\mathrm{NS}\left(\chi^{2}\right.$ test $)$ \\
\hline WHR & 0.95 & $0.93-0.97$ & 0.98 & $0.96-1.00$ & 0.015 \\
\hline Total fat mass $(\%)$ & 30.2 & $27.2-33.2$ & 29.8 & $27.6-32.0$ & NS \\
\hline BMI $\left(\mathrm{kg} / \mathrm{m}^{2}\right)$ & 30.06 & $28.8-31.3$ & 30.9 & $29.7-32.0$ & NS \\
\hline Diastolic BP (mmHg) & 88.6 & $86.5-90.7$ & 90.5 & $88.4-92.5$ & NS \\
\hline Systolic BP (mmHg) & 142.1 & $138.3-145.8$ & 151.7 & $147.1-156.2$ & 0.0014 \\
\hline HDL-cholesterol (mmol/l) & 1.46 & $1.38-1.54$ & 1.26 & $1.18-1.34$ & 0.0009 \\
\hline LDL-cholesterol (mmol/l) & 3.50 & $3.31-3.69$ & 2.94 & $2.74-3.14$ & $<0.0001$ \\
\hline Fasting plasma glucose $(\mathrm{mmol} / \mathrm{l})$ & 5.14 & $5.04-5.24$ & 9.06 & $8.38-9.79$ & $<0.0001$ \\
\hline Fasting insulin (pmol/1) & 45.82 & $40.01-52.48$ & 71.96 & $61.62-84.04$ & $<0.0001$ \\
\hline HOMA2-IR & 0.86 & $0.75-0.99$ & 1.64 & $1.40-1.93$ & $<0.0001$ \\
\hline $\mathrm{HbA}_{1 \mathrm{c}}(\%)$ & 5.52 & $5.47-5.58$ & 7.14 & $6.85-7.44$ & $<0.0001$ \\
\hline Triacylglycerol (mmol/l) & 1.17 & $1.05-1.31$ & 1.56 & $1.35-1.81$ & 0.002 \\
\hline$\dot{V} O_{2} / \mathrm{kg}(1 / \mathrm{kg})$ & 31.0 & $28.6-33.5$ & 24.4 & $22.75-26.00$ & $<0.0001$ \\
\hline \multicolumn{6}{|l|}{ Inflammation } \\
\hline Neutrophils $\left(10^{9} / 1\right)$ & 3.14 & $2.93-3.38$ & 3.81 & $3.56-4.09$ & 0.0002 \\
\hline Plasma CRP (mg/l) & 2.26 & $1.89-2.69$ & 2.93 & $2.45-3.51$ & 0.039 \\
\hline Plasma orosomucoid (g/l) & 0.80 & $0.77-0.83$ & 0.76 & $0.72-0.80$ & NS \\
\hline Plasma TNF- $\alpha$ (ng/l) & 2.40 & $2.29-2.50$ & 2.72 & $2.56-2.88$ & 0.0009 \\
\hline sTNFR2 (ng/l) & 2.28 & $2.2 .6-2.30$ & 2.32 & $2.30-2.34$ & 0.002 \\
\hline IL-6 (ng/l) & 1.27 & $1.08-1.48$ & 1.63 & $1.41-1.90$ & 0.022 \\
\hline \multicolumn{6}{|l|}{ Tissue $T N F$ mRNA } \\
\hline Muscle $T N F$ mRNA (arbitrary units) & 4.13 & $3.67-4.64$ & 4.38 & $3.84-4.99$ & NS \\
\hline Adipose $T N F$ mRNA (arbitrary units) & 2.37 & $2.06-2.74$ & 2.28 & $2.08-2.50$ & NS \\
\hline
\end{tabular}

NS Not significant

Correlation analyses Correlations were calculated for plasma TNF- $\alpha$ and sTNFR2, muscle and adipose TNF- $\alpha$ mRNA, and various parameters of diabetes. As presented in Table 2, plasma TNF- $\alpha$ correlated with several characteristics of the metabolic syndrome: BMI and insulin levels in both groups, and HDL-cholesterol, fasting glucose and $\mathrm{HbA}_{1 \mathrm{c}}$ in the diabetic group. Associations with these parameters were also observed for sTNFR2, which correlated well $(r=0.7)$ with plasma TNF- $\alpha$ concentration. However, regarding TNF mRNA expression in muscle and adipose tissue, no correlation or only weak correlations were found; in regard to muscle, negative correlations were observed with systolic blood pressure $(r=-0.2)$ and triacylglycerol $(r=-0.3)$, whereas muscle TNF mRNA correlated positively with maximal oxygen uptake $(r=0.3)$. In adipose tissue, maximal oxygen uptake correlated negatively with TNF mRNA content.

Plasma TNF- $\alpha$ concentrations were divided into quartiles and related to HOMA2-IR. A clear association between plasma TNF- $\alpha$ and HOMA2-IR was found in both controls and patients with diabetes (Fig. 1a). This was also reflected in plasma sTNFR2; however, in the diabetes group the association was only borderline significant
(Fig. 1b). The mRNA content in muscle or adipose tissue was not associated with insulin resistance as measured by HOMA2-IR (Fig. 1c,d).

In univariate models, plasma TNF- $\alpha$ was associated with several variables, such as obesity and HDL-cholesterol (Table 2). To determine the independent relationship between TNF- $\alpha$ levels and insulin resistance, four models that included successively increasing numbers of confounders were tested for plasma TNF- $\alpha$, plasma sTNFR2 and muscle and adipose tissue TNF mRNA content (Table 3). Only plasma TNF- $\alpha$ in the diabetes group showed a significant relationship, even after adjustment for age, sex, obesity, neutrophil number, IL-6 and $\dot{V} O_{2} / \mathrm{kg}$. No associations were observed for muscle and adipose tissue TNF mRNA content.

TNF- $\alpha$ protein in muscle tissue To examine the production of TNF- $\alpha$ in the muscle tissue, a semiquantitative analysis of TNF- $\alpha$ protein (western blotting) was performed in a subpopulation including eight non-obese controls, eight obese controls, eight non-obese diabetic patients and eight obese diabetic patients. Two forms of TNF- $\alpha$ protein were detected, a cleaved form and the membrane-bound form 
Table 2 Spearman correlations for plasma TNF- $\alpha$, plasma sTNFR2 and TNF- $\alpha$ mRNA in biopsies of muscle and adipose tissue in healthy controls and patients with type 2 diabetes

\begin{tabular}{|c|c|c|c|c|c|c|c|c|}
\hline & \multicolumn{4}{|l|}{ Plasma } & \multicolumn{4}{|c|}{ Tissue $T N F-\alpha$ mRNA } \\
\hline & \multicolumn{2}{|l|}{ TNF- $\alpha$} & \multicolumn{2}{|l|}{ STNFR2 } & \multicolumn{2}{|l|}{ Muscle } & \multicolumn{2}{|c|}{ Adipose tissue } \\
\hline & Controls & Diabetes & Controls & Diabetes & Controls & Diabetes & Controls & Diabetes \\
\hline \multicolumn{9}{|l|}{ Clinical } \\
\hline Age (years) & -0.0370 & 0.1590 & -0.1758 & $0.3040 * *$ & 0.0775 & -0.0205 & 0.1646 & -0.2136 \\
\hline WHR & $0.2130^{*}$ & 0.0956 & $0.2126^{*}$ & 0.1325 & -0.0432 & 0.0596 & -0.0917 & 0.0145 \\
\hline Total fat mass $(\%)$ & $0.2963 * *$ & 0.1422 & $0.4223^{* * *}$ & 0.1150 & -0.1904 & -0.2174 & 0.0526 & -0.1021 \\
\hline BMI $\left(\mathrm{kg} / \mathrm{m}^{2}\right)$ & $0.3109^{* *}$ & $0.2086^{*}$ & $0.4029^{* * *}$ & 0.1662 & -0.1434 & -0.1541 & 0.0475 & -0.0831 \\
\hline Diastolic BP (mmHg) & 0.0074 & 0.1598 & 0.0494 & 0.0667 & -0.1828 & -0.1559 & 0.0750 & -0.0371 \\
\hline Systolic BP (mmHg) & 0.0151 & 0.1064 & -0.0226 & 0.1085 & $-0.2035^{*}$ & 0.0374 & 0.0310 & -0.0983 \\
\hline HDL-cholesterol (mmol/1) & -0.1819 & $0.3050 * *$ & $0.2770 * *$ & $-0.2077 *$ & 0.0631 & 0.0908 & 0.0141 & -0.0171 \\
\hline LDL-cholesterol (mmol/l) & -0.1193 & -0.1681 & $-0.1946^{*}$ & $-0.3474 * * *$ & -0.0770 & -0.1064 & 0.0264 & -0.1891 \\
\hline Fasting plasma glucose $(\mathrm{mmol} / \mathrm{l})$ & -0.0072 & $0.2196^{*}$ & 0.1396 & $0.2024^{*}$ & -0.0871 & -0.0107 & -0.0108 & -0.1491 \\
\hline Fasting insulin $(\mathrm{pmol} / \mathrm{l})$ & $0.2003^{*}$ & $0.2795 * *$ & $0.2670 * *$ & $0.2077^{*}$ & -0.0899 & -0.1437 & -0.1194 & 0.0273 \\
\hline HOMA2-IR & 0.1968 & $0.3088^{* *}$ & $0.2693^{* *}$ & $0.2136^{*}$ & -0.0949 & -0.0883 & -0.1118 & 0.0022 \\
\hline $\mathrm{HbA}_{1 \mathrm{c}}(\%)$ & -0.0066 & $0.2213^{*}$ & -0.0548 & $0.2337^{*}$ & -0.1192 & 0.0423 & 0.0662 & -0.0356 \\
\hline triacylglycerol (mmol/l) & 0.1642 & 0.1625 & 0.0822 & 0.0972 & 0.1218 & $-0.2917 * *$ & 0.0546 & 0.0102 \\
\hline$\dot{V} O_{2} / \mathrm{kg}(1 / \mathrm{kg})$ & $-0.2014 *$ & $-0.2361^{*}$ & $-0.2673 * *$ & $-0.2531 *$ & 0.1499 & $0.2593^{*}$ & $-0.2595^{*}$ & 0.0196 \\
\hline \multicolumn{9}{|l|}{ Inflammation } \\
\hline Neutrophils $\left(10^{9} / 1\right)$ & 0.0170 & 0.0022 & 0.1839 & 0.0890 & -0.1643 & -0.0489 & -0.0892 & -0.0508 \\
\hline Plasma CRP (mg/l) & 0.1745 & 0.1790 & $0.2382 *$ & $0.3032 * *$ & -0.1653 & -0.0277 & 0.0575 & 0.0340 \\
\hline Plasma orosomucoid $(\mathrm{g} / \mathrm{l})$ & 0.0770 & -0.0207 & $0.2364 *$ & 0.1220 & -0.0696 & 0.1525 & -0.0077 & 0.0017 \\
\hline Plasma TNF- $\alpha(n g / 1)$ & - & - & $0.6614^{* * *}$ & $0.7084 * * *$ & 0.1566 & -0.1626 & 0.0121 & -0.0889 \\
\hline sTNFR2 (ng/l) & $0.6614 * * *$ & $0.7084 * * *$ & - & - & 0.0310 & 0.0502 & 0.0680 & 0.0053 \\
\hline IL-6 (ng/l) & $0.4745 * * *$ & $0.2441^{*}$ & $0.4402 * * *$ & $0.3309 * *$ & 0.0073 & 0.0196 & 0.1893 & 0.0325 \\
\hline \multicolumn{9}{|l|}{ Tissue $T N F$ mRNA } \\
\hline Muscle $T N F$ mRNA & 0.1566 & -0.1626 & 0.0310 & 0.0502 & - & - & 0.1893 & 0.0844 \\
\hline Adipose $T N F$ mRNA & 0.0121 & -0.0888 & 0.0753 & 0.0053 & 0.1893 & 0.0844 & - & - \\
\hline
\end{tabular}

(proTNF- $\alpha$ ), with molecular masses of 17 and $28 \mathrm{kDa}$, respectively. The amount of proTNF- $\alpha$ was higher than that of the cleaved form. Recombinant TNF- $\alpha$ protein had a molecular mass similar to the cleaved TNF- $\alpha$ protein (Fig. 2a). Levels of both forms of TNF- $\alpha$ protein were higher in patients with type 2 diabetes than in controls, but there was no significant increase due to obesity (Fig. 2b,c). However, the level of proTNF- $\alpha$ protein was higher in the obese diabetic patients than in the obese controls; the difference between non-obese diabetic patients and nonobese controls was only of borderline significance $(p=0.11$; Fig. 2b).

Since the TNF- $\alpha$ protein content was elevated in skeletal muscle tissue in type 2 diabetic patients, we evaluated the level of TNF- $\alpha$ protein by immunohistochemistry in order to locate it in different fibre types of skeletal muscle. We included eight healthy controls and eight patients with type 2 diabetes, who were matched according to sex, age and BMI. The high level of TNF- $\alpha$ protein was confirmed by immunohistochemistry, which demonstrated homogeneously increased immunostaining within the muscle fibres of diabetic patients. Interestingly, the increased level of TNF$\alpha$ protein was more pronounced in type 2 than in type 1 fibres, although increased levels were not seen in all type 2 fibres but rather in a subgroup of type 2 fibres of the diabetic patients (Fig. 3).

\section{Discussion}

The present study demonstrates that plasma TNF- $\alpha$ is associated with insulin resistance even after adjustment for multiple confounders, such as obesity and other markers of inflammation. Moreover, we found elevated levels of TNF$\alpha$ protein in skeletal muscle biopsies from patients with type 2 diabetes regardless of the level of obesity.

These data add to previous studies on TNF- $\alpha$ and type 2 diabetes, which have either found a similar association [5, 
Fig. 1 Insulin resistance as measured by HOMA2-IR in relation to quartiles of plasma TNF- $\alpha$ (a), plasma sTNFR2 (b), muscle $T N F$ mRNA content (c) and adipose tissue $T N F$ mRNA content (d) in the control and diabetes groups. The $p$ values indicate significant relations to quartiles

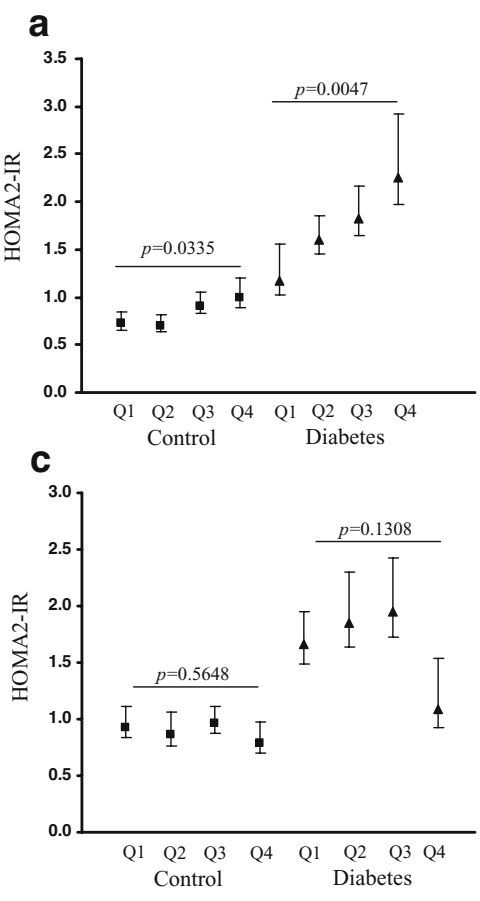

b
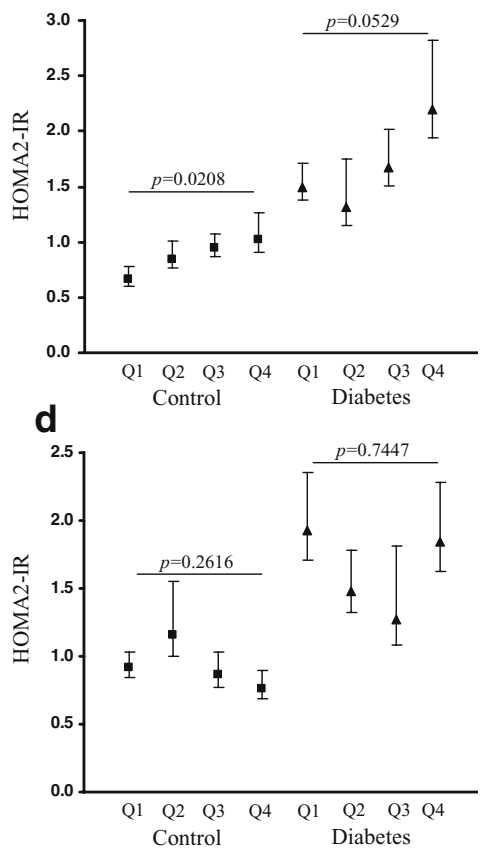

27-29] or no association [6, 7] between TNF- $\alpha$ and insulin resistance. The present study demonstrates that TNF- $\alpha$ is associated with insulin resistance even after adjustment for other inflammatory markers, such as IL-6. Although attempts to improve insulin sensitivity in obese patients with type 2 diabetes by neutralising TNF- $\alpha$, using antiTNF- $\alpha$ antibodies [30] or recombinant TNF receptors [31], have been ineffective, the present study lends support to experimental studies suggesting that TNF- $\alpha$ plays a role in chronic insulin resistance. More recently, we obtained direct evidence for a role of TNF- $\alpha$ in insulin resistance. Thus, infusion of TNF- $\alpha$ into healthy humans impaired insulin signalling and whole-body glucose uptake in humans [10].
Diabetic patients have previously been shown to have higher levels of sTNFR2 in the circulation [6], a finding that can be interpreted as higher activity of TNF- $\alpha$ in the tissues, since sTNFR2 is cleaved from the cell membrane upon activation [24]. Accordingly, in the present study plasma TNF- $\alpha$ and sTNFR2 correlated strongly in controls and diabetic patients, with a Spearman correlation coefficient of $0.66(p<0.001)$ and $0.71(p<0.001)$, respectively. However, when corrected for confounders, sTNFR 2 was not as strongly associated as plasma TNF- $\alpha$ with HOMA2-IR.

There has been much focus on TNF mRNA expression in adipose tissue, especially in relation to obesity. Some studies have demonstrated a positive correlation between HOMA2-IR and adipose tissue TNF mRNA levels [18, 32],

Table 3 Quartiles of plasma TNF- $\alpha$, plasma, sTNFR2, muscle $T N F$ mRNA and adipose $T N F$ mRNA and their relation to insulin sensitivity as measured by HOMA2-IR in five models with different numbers of confounders in healthy controls and patients with type 2 diabetes

\begin{tabular}{|c|c|c|c|c|c|c|c|c|}
\hline & \multicolumn{4}{|c|}{ Controls $(n=103)$} & \multicolumn{4}{|c|}{ Type 2 diabetes $(n=96)$} \\
\hline & \multicolumn{2}{|l|}{ Plasma } & \multicolumn{2}{|c|}{ Tissue $T N F$ mRNA } & \multicolumn{2}{|l|}{ Plasma } & \multicolumn{2}{|c|}{ Tissue $T N F$ mRNA } \\
\hline & TNF- $\alpha$ & STNFR2 & Muscle & Adipose & TNF- $\alpha$ & STNFR2 & Muscle & Adipose \\
\hline Model 1 & 0.0335 & 0.0208 & $(0.5648)$ & $(0.2016)$ & 0.0047 & 0.0529 & $(0.1308)$ & $(0.7447)$ \\
\hline Model 2 & $(0.1500)$ & 0.0527 & $(0.7232)$ & $(0.0681)$ & 0.0027 & 0.0234 & $(0.2146)$ & $(0.1986)$ \\
\hline Model 3 & $(0.1177)$ & 0.3444 & $(0.8639)$ & 0.1663 & 0.0122 & 0.0789 & $(0.4370)$ & $(0.2223)$ \\
\hline Model 4 & 0.2062 & 0.3095 & $(0.4712)$ & $(0.0666)$ & 0.0145 & 0.1022 & $(0.6645)$ & $(0.2921)$ \\
\hline Model 5 & 0.2122 & 0.3563 & $(0.1460)$ & 0.2265 & 0.0263 & 0.1153 & $(0.5348)$ & $(0.3495)$ \\
\hline
\end{tabular}

The analysis is based on a general linear model and the $p$ values are stated; parentheses indicate that the overall model was not significant. Model 1: crude model; Model 2: model $1+$ age + sex; Model 3: Model $2+$ obesity + WHR; Model 4: Model $3+$ neutrophils + plasma IL-6; Model 5: Model $4+\dot{\mathrm{V}} \mathrm{O}_{2} / \mathrm{kg}$ 


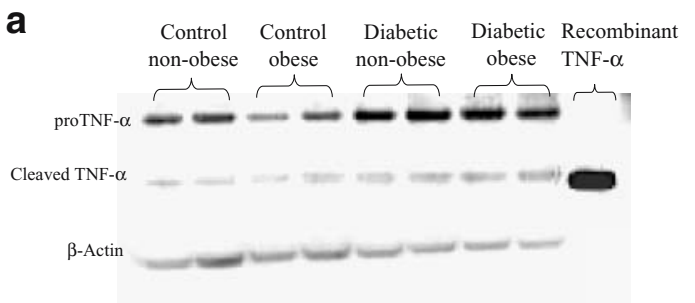

b

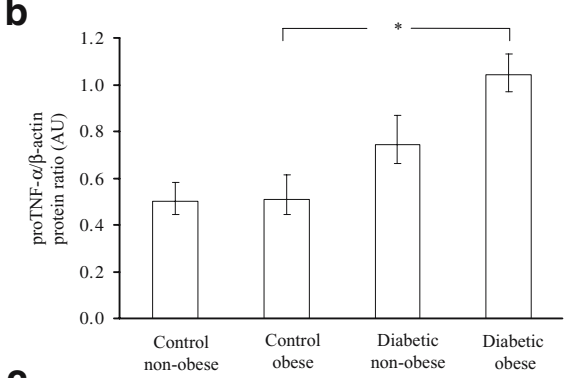

C

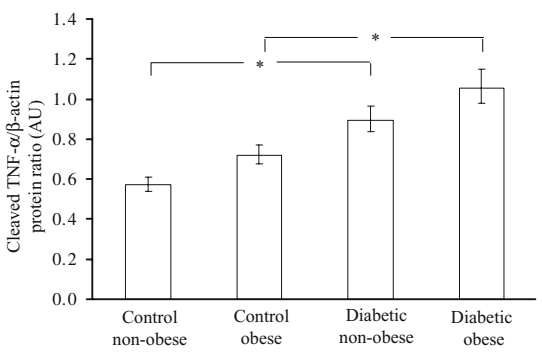

Fig. 2 Western blot analysis of TNF- $\alpha$ protein in the skeletal muscle of healthy controls (eight with normal weight and eight obese) and diabetics (eight with normal weight and eight obese). a Representative blots. Recombinant human TNF- $\alpha$ demonstrated a molecular mass similar to that of cleaved TNF- $\alpha$ in muscle tissue. The intensity of the bands was quantified by densitometry. $\beta$-Actin was measured as a reference and TNF- $\alpha$ (cleaved and proTNF- $\alpha$ ) was expressed as a ratio with respect to $\beta$-actin, thereby reducing differences in the total amount of protein and the loading and blotting procedure. $\mathbf{b}$ Ratio of proTNF- $\alpha$ to $\beta$-actin. One-way ANOVA: diabetes $p=0.0002$; obese $p=0.1874$; diabetes $\times$ obese $p=\mathrm{NS}$. $\mathbf{c}$ Ratio of cleaved TNF- $\alpha$ to $\beta$-actin. One-way ANOVA: diabetes $p<0.0001$; obese $p<0.0079$; diabetes $\times$ obese $p=\mathrm{NS}$. Data are presented as means \pm SEM. *Significant difference between groups indicated according to ANOVA with post hoc Student's $t$ test. AU, arbitrary units

whereas others have not [33]. These studies [18, 32, 33] are small, with $\sim 20$ subjects. A recent study compared type 2 diabetic male patients $(n=56)$ with healthy controls $(n=51)$. TNF mRNA was measured in the subcutaneous adipose tissue and there was a higher level only in a subgroup of diabetic patients with a BMI $>40 \mathrm{~kg} / \mathrm{m}^{2}$ [34]. In the present study only eight men (three healthy and five with diabetes) had a BMI $>40 \mathrm{~kg} / \mathrm{m}^{2}$ and no difference was observed in this subgroup. Visceral fat in particular has been suggested to have a high level of TNF- $\alpha[27,35]$, which is a possible explanation for the lack of difference in subcutaneous adipose tissue between controls and diabetic patients in the present study. It has not been possible to demonstrate secretion of TNF- $\alpha$ protein from subcutaneous adipose tissue using arteriovenous differences [21,36], making it

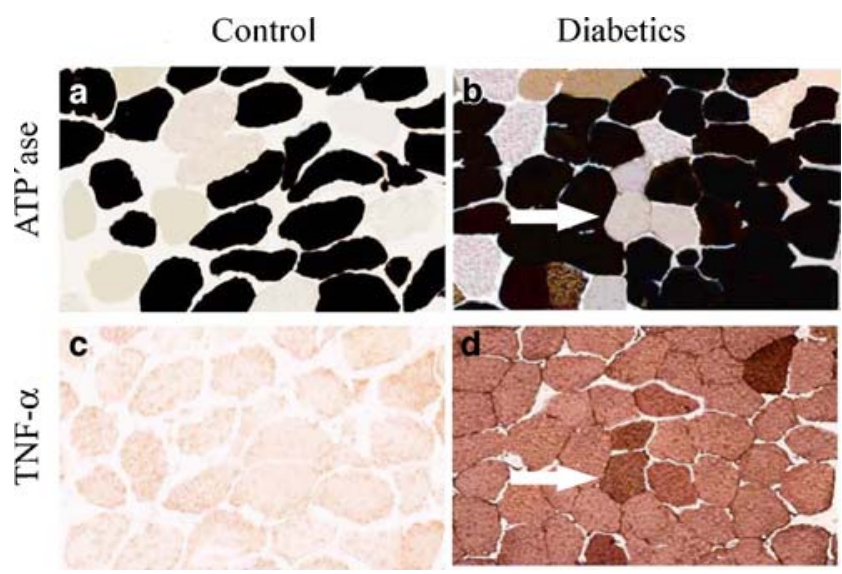

Fig. 3 Representative sections of muscle from a control and a diabetic patient. a, b Fibre types are distinguished by ATPase stain. c, d Parallel sections stained for TNF- $\alpha$. The arrows indicate a type 2 fibre. A subpopulation of type 2 fibres shows increased TNF- $\alpha$ protein levels compared with type 1 fibres; however, this was not observed for all fibres classified as type 2

unlikely that TNF- $\alpha$ derived from adipose tissue is acting on the skeletal muscle tissue.

Very few studies have attempted to compare the $T N F$ mRNA content in skeletal muscle between type 2 diabetics and healthy controls. Saghizadeh et al. [13] compared TNF mRNA content from five healthy subjects with five insulinresistant and five diabetic patients and found an increase in $T N F$ mRNA in insulin-resistant and diabetic patients. Furthermore, the amount of TNF mRNA correlated negatively with insulin sensitivity. Surprisingly, in the present study (94 controls and 83 diabetic patients), the level of TNF mRNA did not differ between the groups and correlation analysis of relevant clinical parameters revealed no association with the metabolic syndrome. These data were somewhat unexpected; however, patients with type 2 diabetes who performed a resistance exercise demonstrated improved insulin sensitivity despite an increase in $T N F$ mRNA transcripts [37], suggesting no association of insulin sensitivity with TNF mRNA content in skeletal muscle. Taking these results together, the TNF mRNA content in muscle has limited clinical significance in relation to insulin resistance.

A higher level of TNF- $\alpha$ protein in skeletal muscle of patients with type 2 diabetes compared with healthy controls has been demonstrated by a modified ELISA in homogenised muscle biopsies [38], and it has been shown that primary muscle cell cultures derived from diabetic patients secrete more TNF- $\alpha$ protein into the medium than primary muscle cell cultures established from healthy controls [13]. In line with these data, in the present study we also observed a higher level of TNF- $\alpha$ protein in muscle from diabetic patients.

Immunohistochemistry demonstrated that $\mathrm{TNF}-\alpha$ protein accumulates within muscle fibres. Insulin-resistant and obese patients have a higher proportion of type 2 muscle fibres than 
healthy controls $[39,40]$, which is of interest since the type 2 muscle fibres appeared to contain more TNF- $\alpha$ than type 1 fibres. However, this difference is not reflected in $T N F$ mRNA levels, as human soleus and triceps muscles express similar amounts of TNF mRNA, despite the fact that the soleus and triceps predominantly consist of type 1 and type 2 muscle fibres, respectively. This is in line with results from studies in which single fibre were dissected out, which found no difference in TNF mRNA content between type 1 and 2 fibres from the human vastus lateralis muscle [41]. Taking these results together, it appears that TNF- $\alpha$ levels in muscle are not regulated at the transcriptional level, which would explain the lack of association found when studying the TNF mRNA contents of muscle and adipose tissue.

In conclusion, the present study demonstrates that the plasma TNF- $\alpha$ level is associated with insulin resistance even after adjustment for multiple confounders, and that the level of TNF- $\alpha$ protein in muscle is elevated in patients with type 2 diabetes, especially in type 2 muscle fibres. Our findings with regard to TNF- $\alpha$ protein levels in plasma and skeletal muscle indicate that measurement of the $T N F$ mRNA content in adipose or muscle tissue provides no information with regard to the degree of insulin resistance.

Acknowledgements The authors are grateful for the excellent technical assistance of H. Villumsen, R. Rousing and B. Starup Mentz. This study was funded by the Commission of the European Communities (Contract No. LSHM-CT-2004-005272 EXGENESIS), the Novo Nordisk Foundation and the Danish Diabetes Association. The Centre of Inflammation and Metabolism is supported by a grant from the Danish National Research Foundation (DG 02-512-555). The Copenhagen Muscle Research Centre is supported by grants from the University of Copenhagen, the Faculties of Science and of Health Sciences at this university, and the Copenhagen Hospital Corporation. The study also received support from the Danish Medical Research Council and the Danish Natural Research Council.

Duality of interest The authors declare that there is no duality of interest associated with this manuscript.

\section{References}

1. Pickup JC, Crook MA (1998) Is type II diabetes mellitus a disease of the innate immune system? Diabetologia 41:1241-1248

2. Pickup JC (2004) Inflammation and activated innate immunity in the pathogenesis of type 2 diabetes. Diabetes Care 27:813-823

3. Feingold KR, Grunfeld C (1992) Role of cytokines in inducing hyperlipidemia. Diabetes 41(Suppl 2):97-101

4. Winkler G, Salamon F, Harmos G et al (1998) Elevated serum tumor necrosis factor-alpha concentrations and bioactivity in type 2 diabetics and patients with android type obesity. Diabetes Res Clin Pract 42:169-174

5. Mishima Y, Kuyama A, Tada A, Takahashi K, Ishioka T, Kibata M (2001) Relationship between serum tumor necrosis factor-alpha and insulin resistance in obese men with type 2 diabetes mellitus. Diabetes Res Clin Pract 52:119-123
6. Fischer CP, Perstrup LB, Berntsen A, Eskildsen P, Pedersen BK (2005) Elevated plasma interleukin-18 is a marker of insulinresistance in type 2 diabetic and non-diabetic humans. Clin Immunol 117:152-160

7. Carey AL, Bruce CR, Sacchetti M et al (2004) Interleukin-6 and tumor necrosis factor-alpha are not increased in patients with type 2 diabetes: evidence that plasma interleukin- 6 is related to fat mass and not insulin responsiveness. Diabetologia 47:1029-1037

8. Hotamisligil GS, Peraldi P, Budavari A, Ellis R, White MF, Spiegelman BM (1996) IRS-1-mediated inhibition of insulin receptor tyrosine kinase activity in TNF-alpha- and obesity-induced insulin resistance. Science 271:665-668

9. Miles PD, Romeo OM, Higo K, Cohen A, Rafaat K, Olefsky JM (1997) TNF-alpha-induced insulin resistance in vivo and its prevention by troglitazone. Diabetes 46:1678-1683

10. Plomgaard P, Bouzakri K, Krogh-Madsen R, Mittendorfer B, Zierath JR, Pedersen BK (2005) Tumor necrosis factor-alpha induces skeletal muscle insulin resistance in healthy human subjects via inhibition of Akt substrate 160 phosphorylation. Diabetes 54:2939-2945

11. Bouzakri K, Zierath JR (2007) MAP4K4 gene silencing in human skeletal muscle prevents tumor necrosis factor-alpha-induced insulin resistance. J Biol Chem 282:7783-7789

12. DeFronzo RA, Gunnarsson R, Bjorkman O, Olsson M, Wahren J (1985) Effects of insulin on peripheral and splanchnic glucose metabolism in noninsulin-dependent (type II) diabetes mellitus. J Clin Invest 76:149-155

13. Saghizadeh M, Ong JM, Garvey WT, Henry RR, Kern PA (1996) The expression of TNF alpha by human muscle. Relationship to insulin resistance. J Clin Invest 97:1111-1116

14. Montes de OM, Torres SH, De SJ, Mata A, Hernandez N, Talamo $\mathrm{C}$ (2005) Skeletal muscle inflammation and nitric oxide in patients with COPD. Eur Respir J 26:390-397

15. Boule NG, Haddad E, Kenny GP, Wells GA, Sigal RJ (2001) Effects of exercise on glycemic control and body mass in type 2 diabetes mellitus: a meta-analysis of controlled clinical trials. JAMA 286:1218-1227

16. Greiwe JS, Cheng B, Rubin DC, Yarasheski KE, Semenkovich CF (2001) Resistance exercise decreases skeletal muscle tumor necrosis factor alpha in frail elderly humans. FASEB J 15:475-482

17. McKeigue PM, Pierpoint T, Ferrie JE, Marmot MG (1992) Relationship of glucose intolerance and hyperinsulinaemia to body fat pattern in south Asians and Europeans. Diabetologia 35:785-791

18. Hotamisligil GS, Arner P, Caro JF, Atkinson RL, Spiegelman BM (1995) Increased adipose tissue expression of tumor necrosis factor-alpha in human obesity and insulin resistance. J Clin Invest 95:2409-2415

19. Kern PA, Ranganathan S, Li C, Wood L, Ranganathan G (2001) Adipose tissue tumor necrosis factor and interleukin-6 expression in human obesity and insulin resistance. Am J Physiol Endocrinol Metab 280:E745-E751

20. Xu H, Uysal KT, Becherer JD, Arner P, Hotamisligil GS (2002) Altered tumor necrosis factor-alpha (TNF-alpha) processing in adipocytes and increased expression of transmembrane TNF-alpha in obesity. Diabetes 51:1876-1883

21. Mohamed-Ali V, Goodrick S, Rawesh A et al (1997) Subcutaneous adipose tissue releases interleukin-6, but not tumor necrosis factor-alpha, in vivo. J Clin Endocrinol Metab 82: 4196-4200

22. Weisberg SP, McCann D, Desai M, Rosenbaum M, Leibel RL, Ferrante AW Jr (2003) Obesity is associated with macrophage accumulation in adipose tissue. J Clin Invest 112:1796-1808

23. Fernandez-Real JM, Lainez B, Vendrell J et al (2002) Shedding of TNF-alpha receptors, blood pressure, and insulin sensitivity in 
type 2 diabetes mellitus. Am J Physiol Endocrinol Metab 282: E952-E959

24. Higuchi M, Aggarwal BB (1994) TNF induces internalization of the p60 receptor and shedding of the p 80 receptor. J Immunol 152: $3550-3558$

25. Wallace TM, Levy JC, Matthews DR (2004) Use and abuse of HOMA modeling. Diabetes Care 27:1487-1495

26. Bergstrom J (1975) Percutaneous needle biopsy of skeletal muscle in physiological and clinical research. Scand J Clin Lab Invest 35:609-616

27. Bertin E, Nguyen P, Guenounou M, Durlach V, Potron G, Leutenegger M (2000) Plasma levels of tumor necrosis factoralpha (TNF-alpha) are essentially dependent on visceral fat amount in type 2 diabetic patients. Diabetes Metab 26:178-182

28. Katsuki A, Sumida Y, Murashima S et al (1998) Serum levels of tumor necrosis factor-alpha are increased in obese patients with noninsulindependent diabetes mellitus. J Clin Endocrinol Metab 83:859-862

29. Lechleitner M, Herold M, Dzien-Bischinger C, Hoppichler F, Dzien A (2002) Tumour necrosis factor-alpha plasma levels in elderly patients with type 2 diabetes mellitus - observations over 2 years. Diabet Med 19:949-953

30. Ofei F, Hurel S, Newkirk J, Sopwith M, Taylor R (1996) Effects of an engineered human anti-TNF-alpha antibody (CDP571) on insulin sensitivity and glycemic control in patients with NIDDM. Diabetes 45:881-885

31. Paquot N, Castillo MJ, Lefebvre PJ, Scheen AJ (2000) No increased insulin sensitivity after a single intravenous administration of a recombinant human tumor necrosis factor receptor: Fc fusion protein in obese insulin-resistant patients. J Clin Endocrinol Metab 85:1316-1319

32. You T, Yang R, Lyles MF, Gong D, Nicklas BJ (2005) Abdominal adipose tissue cytokine gene expression: relationship to obesity and metabolic risk factors. Am J Physiol Endocrinol Metab 288: E741-E747

33. Hube F, Birgel M, Lee YM, Hauner H (1999) Expression pattern of tumour necrosis factor receptors in subcutaneous and omental human adipose tissue: role of obesity and non-insulin-dependent diabetes mellitus. Eur J Clin Invest 29:672-678

34. Chacon MR, Fernandez-Real JM, Richart C et al (2007) Monocyte chemoattractant protein- 1 in obesity and type 2 diabetes. Insulin sensitivity study. Obesity (Silver Spring) 15: 664-672

35. Good M, Newell FM, Haupt LM, Whitehead JP, Hutley LJ, Prins JB (2006) TNF and TNF receptor expression and insulin sensitivity in human omental and subcutaneous adipose tissue - influence of BMI and adipose distribution. Diab Vasc Dis Res 3: 26-33

36. Mohamed-Ali V, Goodrick S, Bulmer K, Holly JM, Yudkin JS, Coppack SW (1999) Production of soluble tumor necrosis factor receptors by human subcutaneous adipose tissue in vivo. Am J Physiol 277:E971-E975

37. Gordon PL, Vannier E, Hamada K et al (2006) Resistance training alters cytokine gene expression in skeletal muscle of adults with type 2 diabetes. Int J Immunopathol Pharmacol 19:739-749

38. Torres SH, De Sanctis JB, de LB, Hernandez N, Finol HJ (2004) Inflammation and nitric oxide production in skeletal muscle of type 2 diabetic patients. J Endocrinol 181:419-427

39. Kriketos AD, Pan DA, Lillioja $S$ et al (1996) Interrelationships between muscle morphology, insulin action, and adiposity. Am J Physiol 270:R1332-R1339

40. Marin P, Andersson B, Krotkiewski M, Bjorntorp P (1994) Muscle fiber composition and capillary density in women and men with NIDDM. Diabetes Care 17:382-386

41. Yang Y, Jemiolo B, Trappe S (2006) Proteolytic mRNA expression in response to acute resistance exercise in human single skeletal muscle fibers. J Appl Physiol 101:1442-1450 